\title{
Marriage Harmony: The Role Of Empathy And Forgiveness
}

\author{
Faisal Adnan Reza, Subhan Azrin Sudirman, Mubarak Mubarak \\ Universitas Islam Negeri (UIN) Raden Intan Bandar Lampung, Universitas Islam Negeri \\ (UIN) Imam Bonjol Padang, Universitas Islam Negeri (UIN) Antasari Banjarmasin
}

\begin{abstract}
The phenomenon of forgiveness is an interesting behavior to discuss, especially in marital relationships. This article aims to examine the factors that influence forgiveness behavior in a marital relationship as well as to find out whether empathy is related to forgiveness behavior. The method used in this study is a mixed method with a population of 30 families or 60 subjects. The instruments used in addition to interviews were the scale of empathy and the scale of forgiveness. The analysis technique used is the Pearson correlation. The results showed that there was a significant relationship between empathy and forgiveness behavior. Meanwhile, the factors that influence forgiveness behavior are empathy, social and religious norms, interdependence between partners, and commitment.
\end{abstract}

Keyword: Empathy; Forgiveness; Marriage

\begin{abstract}
Abstrak
Fenomena memaafkan merupakan perilaku yang menarik untuk dibahas, terutama dalam hubungan perkawinan. Artikel ini bertujuan untuk mengetahui faktor-faktor yang memengaruhi perilaku memaafkan dalam sebuah hubungan perkawinan sekaligus mengetahui juga apakah empati berhubungan dengan perilaku memafkan. Metode yang digunakan dalam penelitian ini adalah metode campuran dengan populasi sebanyak 30 kepala keluarga atau 60 orang subjek. Instrumen yang digunakan selain wawancara, adalah skala empati dan skala pemaafan. Teknik analisis yang digunakan adalah korelasi Pearson. Hasil penelitian menunjukkan ada hubungan yang signifikan antara empati dengan perilaku memaafkan. Sementara faktor-faktor yang memengaruhi perilaku memaafkan adalah empati, norma sosial dan agama, interdependensi antar pasangan, dan komitmen.
\end{abstract}

Kata Kunci : Empati; Pemaafan; Perkawinan

Engaging in an intimate relationship, in this case, marriage will lead the individual to a change in his life. If two people form a relationship, they will be bound together in one life. Whatever the partner does will effect the other partner. Of course, these relationships will be colored by various kinds of strong emotions that arise as a consequence of the formation of 
these relationships. Other people can make someone feel sad or happy, tell the latest gossip, help do something, criticize opinions, give gifts or advice or even irritate anger, and hate (Boiger \& Mesquita, 2012).

Involvement in a close relationship, especially a marriage relationship, can bring about quite a fundamental change in a person's life. For example, the occurrence of changes in daily activities in previous lives. This arises as a result of a person's desire to adjust their activities to those of their partners (Fabes, Peterson, \& Steinmetz, 2002). Involvement in a romantic relationship also changes the way each partner communicates.

Humans as individuals are unique. The household is to unite two uniqueness, the uniqueness of the wife and the uniqueness of the husband. If the uniqueness of the husband and wife becomes a synergy, the household is able to perceive the stimulus proportionally, but if the two uniqueness are contradictory, then everything that exists will become a principle, and responds with a principal attitude based on each other's uniqueness in other words, there is conflict within the household (Mubarok, 2009).

Conflicts that occur in a marriage relationship can be caused by various things, including; incompatibility, external sources of stress, and temptations outside the relationship. This conflict or negative interaction is very natural in an intense relationship. The difference in family and personal backgrounds is one factor that causes the conflict.

In the annual records of the National Women's Commission in 2021, the number of cases of violence against women in 2020 was 299,911, consisting of cases handled by: [1] District Courts/Religious Courts totaling 291,677 cases; [2] The partner service agency of the National Commission for Women was 8,234 cases; and [3] The Service and Referral Unit of the National Commission on Women totaled 2,389 cases, with a record that 2,134 cases were gender-based and 255 of which were cases that were not gender-based or provided information (komnasperempuan.go.id).

Brock and Lawrence (2014) classify various conflicts into three categories. First. Specific behavior is some type of conflict originating from one party, such as getting drunk at a party or forgetting to buy milk, or also when one party fails to provide the reward the other party expects. Second, norms and roles are other conflicts that arise from matters surrounding the 
rights and obligations of the parties involved, for example, because one of the parties has broken a promise, because of the lack of balance in the reciprocal relationship or because one person neglects a mutually agreed task. Third, personal dispositions are conflicts that arise as a result of a person displaying distinctive behavior in response to the attitudes and intentions of his colleagues. A person may complain that his friend is lazy, indifferent, and lacks selfdiscipline.

The conflict that occurs certainly greatly affects the emotional state of the individuals involved in it. One of the interpersonal emotions that involves experiences in everyday life is known as "emotional wounds". Some examples of emotional wounds include: disappointment, sadness, irritation, resentment, anger, hatred, feeling humiliated, disrespected, humiliated, hurt, and resentful. Psychologically, the emotional pain caused by an interpersonal event can be as acute and as displeasing as physical pain from bodily injury. Mental injuries often last even longer than bodily injuries and have the potential to be the cause of the end of a relationship (McCullough, et al., 1998).

The increasing divorce rate in Indonesia is one clear proof that relations are ending because of conflict. Various causes of divorce have been revealed, for example; incompatibility, economy, and domestic violence. Increasing divorce rates also occur in several cities. In the city of Padang during the period 2017-2019, there were 3615 divorces, and continues to experience an increasing trend every year (Basri, 2020). The cause of divorce is mostly due to domestic violence and the presence of a third person in the marriage.

As has been discussed in many writings on domestic violence (KDRT), in addition to physical injuries, victims of domestic violence also experience psychological wounds (inner wounds) which take longer and are difficult to heal because they cause deep psychological trauma. Other causes of violence, such as persecution, arose as a result of a momentary outburst of anger or anger, and heartache that had accumulated (revenge) was also common. This further emphasizes that conflicts that result in emotional wounds (anger, hurt, and revenge) can happen to anyone, even with a partner in a close relationship.

In one study, Gottman tested self-reports of emotional experiences of partners in a romantic relationship during the most positive and negative moments that occur in a setting 
laboratory. From the results of these studies, Gottman reported the assessment of couples on the affection checklist divided into three kinds of emotional responses. The first affective response is a generally positive feeling characterized by kindness, love, and relationship-constructive behavior. The second affective response, which Gottman calls the perceived pain-attack feeling, is characterized by whining, victim's innocence, fear, and anxiety. The third affective response, called appropriate anger. This response is characterized by anger, humiliation, and thoughts of revenge on the partner (McCullough, et al., 1998).

In connection with the research conducted by Gottman, two assumptions arise, that the two negative affective statements that characterize interpersonal interactions around interpersonal relationships, as in Gottman's research, match two elements of the motivational system that influence a person's response to their partner's attacks (McCullough, et al., 1998). In particular, McCullough, et al., (1998) stated that (a) the feeling of pain-attack that was felt was compatible with the motivation to avoid contact, both personally and psychologically with the person who hurt the feeling (avoidance); and (b) feelings of anger, which in their place are compatible with the motivation for taking revenge or hurting the person who hurt the feeling (revenge). These two different motivations work together to create a psychological state, which people commonly refer to as forgiveness.

Someone is considered to be forgiving if it inhibits feelings of revenge or builds positive feelings, behavior, and cognition (Fincham, Paleari, \& Regalia, 2002). For example, when forgiving, the individual may identify the causative factors for the situation that cause the offender to commit offensive actions (cognitive), feel sympathy or feel sorry for the offender (affective) and discuss possible problem solving or help the offender (behavior). For most people, forgiving people who have hurt their feelings is very difficult, even though forgiveness has been taught and trained since childhood. Social and religious norms also provide teachings on forgiveness, namely that forgiving someone who has hurt someone is considered a noble act.

Islam teaches its adherents to have a forgiving behavior, and this is one of the noble qualities, Allah SWT says in Surat An nur verse 22:

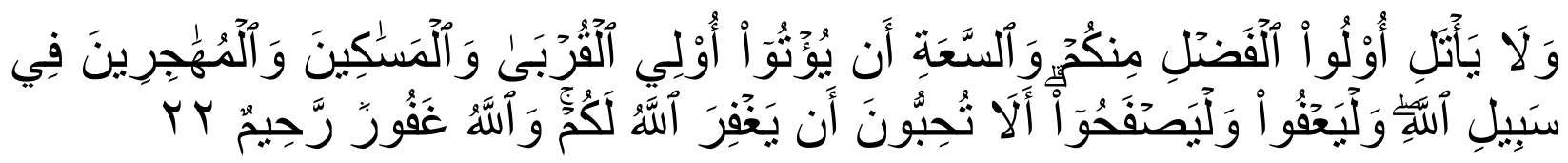


"Do not let the people of virtue and affluence among you swear to suspend donations to their relatives, the needy, and the emigrants in the cause of Allah. Let them pardon and forgive. Do you not love to be forgiven by Allah? And Allah is All-Forgiving, Most Merciful"

As for the reason for the revelation of this verse about the oath of Abu Bakr (may God bless him) that he will not give anything to his relatives or others who are involved in spreading false news about Aisyah (radiyallahu anha) they after being punished for their actions (Nugroho, 2020). The above verse also explains that forgiving is an act loved by Allah SWT, those who get forgiveness will calm their souls because of forgiveness. Forgiving is one of the acts that forgive the mistakes of others because Allah SWT is Most Forgiving.

In Tafsir al-Misbah, it is explained that the word afw means erasing and destroying, as well as uprooting something, erasing here means that eliminating everything. This means that every mistake made by others to us and we forgive them, then let us erase and destroy the mistakes he has made, not forgiveness that only comes out of the mouth but his heart does not (Shihab, 2002). Furthermore, there is the word yasfu which comes from the words ash-shafh and shafhat which means a new leaf, the meaning is that someone has to open a new leaf, pure white has never been tainted by something, so if we have forgiven others we should really forget the mistakes that have been doing, so that there are no more bad records about the mistakes that have been done by the perpetrators (Shihab, 2002).

Forgiveness is a set of motivations to change someone not to take revenge and reduce the urge to nurture hatred for the offending party and increase the urge to conciliate the relationship with the offending party (Chaplin, 2019). Some people can sincerely forgive people who have hurt them. But in most cases, people often can't forgive the person who has hurt them, even though verbally they have already forgiven.

Friesen, Fletcher, and Overall (2005) suggest that this false forgiveness may be motivated by the victim's desire to fulfill a socially or religiously determined role. Victims may also forgive because of moral demands or win power over the perpetrator. There are also cases where people who have been hurt repeatedly by their partners forgive the perpetrator and the relationship with the partner continues again. 
Humans are born with emotions, there are two kinds of emotions according to their nature, namely negative emotions, and positive emotions. Negative emotions like anger while positive emotions like empathy and sympathy. Empathy according to Lanzoni (2018), is an activity to understand what other people are thinking and feeling, as well as what the person is feeling, regarding the conditions that are being experienced by others, without the person concerned losing his/her control.

The best result of empathy is the emergence of helpful behavior, the meaning of helping behavior here is as long as the person can improve the condition of others or make them better (Howe, 2013). Helping by giving forgiveness to people who have hurt them, aims to relieve the anxiety of the injured person and reduce depression that occurs when conflicts occur in marital relationships, and make household interactions more positive. So this sense of empathy is expected to be able to generate forgiving behavior.

Conflicts in the household can occur at any time due to various factors, be it internal or external, such as the economy and the inability to control emotions. The conflict that occurs will make a person's emotions unstable and even lead to physical aggression. In cases of domestic violence, there is even a persistent pattern, namely the existence of a cycle of violence which consists of three phases, namely: the first phase, the stage of increasing tension; the second phase of the persecution stage; and the third phase is the honeymoon stage which is marked by an apology from the perpetrator of domestic violence and forgiveness by the victim, and the cycle is repeated and repeated. These things are what attract researchers to find out how people forgive people who have hurt them.

Psychological research on forgiveness behavior has increased over the past 10 years, especially from a developmental and clinical perspective (Macaskill, 2012; Wade, Hoyt, Kidwell, Worthington, \& Everett, 2014; Toussaint, Owen, \& Cheadle, 2012; Riek \& Mania, 2012). Some evidence suggests that forgiveness improves marital adjustment and reduces depression, anxiety, and anger-hate behavior patterns (Enright, Gassin, \& Wu, 2006).

To explain and understand how forgiving behavior occurs in a marital relationship, this study will also use the theory of interdependence from Thibaut and Kelly (Rusbult \& Verette, 1991). Likewise, to explain how empathy becomes a facilitator that mediates the emergence of 
forgiving behavior. Interdependency theory assumes that people are always examining the benefits and costs or the advantages and disadvantages of a particular relationship. These benefits take the form of feeling loved and getting financial assistance, while losses are in the form of negative consequences of a relationship such as the amount of time wasted due to conflict. People who are in a particular relationship usually don't write about the good or bad aspects of a relationship. Nonetheless, individuals are aware of the disadvantages and costs involved in it. In particular, the focus of research is on the overall results obtained from a relationship, namely whether the relationship is beneficial for the person concerned or not (Bantham, Celuch, \& Kasouf, 2003). This theory also describes the structure of the emergence of interdependence results that will shape motivation and behavior in relationships between individuals.

Several prosocial phenomena, such as cooperation, altruism, and inhibition of aggression, appear to be motivated by empathy for others (Riess, 2017). Considering this, researchers assume that because forgiving behavior is similar to other prosocial phenomena, so it is also motivated by empathy. Although empathy is inherently an affective phenomenon, the ability to take other people's cognitive (perspectives taking) appears to be an important cognitive tool of empathic affection that may be relevant for understanding how empathy affects development.

Empathy is a person's ability to share other people's feelings or experiences. This ability for empathy is closely related to role takeover. Through empathy for the offending party, one can understand the feelings of the offending party to feel guilty and depressed due to the painful behavior, for that reason several studies have shown that empathy affects the forgiveness process (Cuff, Brown, Taylor, \& Howat, 2014). Empathy also explains the socialpsychological variables that influence forgiveness, namely apologies from the offending party. When the perpetrator apologizes to the party who was hurt, it can make the victim more empathetic and then motivated to forgive him.

Although previous researchers have stated and reviewed evidence to support that empathy and levels of emotional pain and levels of relationships and personality levels may influence forgiveness behavior, the notion of forgiveness as a motivational phenomenon, driven 
in particular by empathy, leads to the hypothesis that empathy is wrong. one of the most important mediators of forgiveness behavior.

Forgiveness is a very complex journey including the ability to change our affective, cognitive, and behavioral systems. Worthington (2005) notes that as a basic aspect of all kinds of relationships, forgiveness has the potential to facilitate a more integrated science in close relationships. McCullough, Kurzban, and Tabak, (2013) stated that forgiveness is related to communication and conflict resolution.

According to Griffin, Worthington, Lavelock, Wade, and Hoyt (2015), accepting other people is not the same as forgiving. Accepting other people occurs when the other person is considered a good person. Meanwhile, forgiving others occurs when those other people do bad things to us. Forgiveness is the willingness to leave the hurtful mistakes of the past, stop looking for value in anger and hatred and dismiss the desire to hurt others or oneself. A similar opinion is expressed by Braithwaite, Selby, and Fincham (2011) who suggest that forgiveness is a set of motivations to change a person not to take revenge, and reduce the urge to maintain hatred against the hurting party and increase the urge to conciliate relationships with the offending party.

Forgiving someone automatically makes him a good individual. This is not the case, according to Wardhati and Faturochman (2006), many people forgive by doing the martyr's way. In the sense that the individual sacrifices his feelings, sometimes they harbor feelings, tolerate the behavior of others, then forgive them very easily. Behind this action contains the intention to show moral superiority to one's partner through behavior such as wanting to sacrifice feelings, but in reality, this reward does not necessarily get it. On the other hand, the guilty party becomes less responsive to the attitude of the other party because they feel that they do not care about themselves anymore and do not at all try to give more appreciation for the victim's martyrdom behavior. There is also an assumption that forgiveness automatically resolves conflict so that the relationship can continue. In certain cases, it is necessary to forgive according to reason. However, this does not automatically resolve interpersonal conflict, which becomes a problem in forgiveness, forgiveness can be given without changing attitudes and emotions towards the guilty person (Wardhati \& Faturochman, 2006). 


\section{Methods}

This research will use mixed methods, namely research that uses two methods, qualitative methods and quantitative methods (Creswell, 2012). Mixed methods when one of the existing methods is deemed unable to explain the phenomenon to be disclosed, then two methods are used at once which are useful to complement or cover up the shortcomings. Qualitative methods are used to see how the process of forgiveness occurs in a marriage relationship and what are the factors that motivate forgiveness behavior. Quantitative methods are used to see whether empathy plays a role in facilitating forgiving behavior in partners who have hurt them.

The population in this study are people who live in Padang City, West Sumatra Province, Indonesia, with as many as 30 families (60 people) and are married and have age criteria of 26-51 years. The samples used were 15 households or as many as 30 people. The sampling technique used purposive sampling. Collecting data using interviews and also scales, namely the scale of empathy and the scale of forgiveness. The empathy scale is based on Davis's theory with aspects of perspective taking, fantasy, empathic-concern, and personal distress. The forgiveness scale is prepared based on McCullough's theory by revealing three aspects, namely: revenge, avoidance, and positive responses. The data analysis technique uses Pearson's correlation analysis technique to determine the relationship between empathy and forgiveness behavior, while the technique is a depth interview used to find data on how the process of forgiveness occurs.

\section{Results}

The implementation of data collection in the form of a narrative and scale, in the first part, contains a thank you sheet and a notification that this research is solely for scientific purposes and has nothing to do with bad or good and right or wrong judgments if someone forgives or does not forgive their partner. After that, continue with the identity data. Form A2 contains a narrative method containing life stories (conflicts that occur in the household either 
as victims or perpetrators). Form A3 Scale of forgiveness behavior consisting of 22 statement items, and Form A4 on the empathy scale consisting of 40 statement items.

The second stage of data retrieval is that this data is collected using technique depth interview. The first data collection was carried out by meeting with respondents who aimed to build a rapport and determine an interview schedule. The respondents in the interview totaled 4 people, namely 2 husbands and 2 wives. The selection of respondents is based on the sensitivity of the respondent's case as revealed in the narrative written by the respondent in the first stage of data collection.

Of the 30 respondents who wrote the narrative of the conflict with their partner, 20 (66.66\%) wrote two narratives, both as the victim (the person who was hurt by their partner) and the perpetrator (the person who hurt their partner), while 10 people $(33.33 \%)$ ) wrote the narrative only as a victim.

The narrative method used in this study has succeeded in uncovering many conflict incidents involving respondents and their partners, either as victims or perpetrators. As for the causes of hurt feelings, among others, problems with partner miscommunication (13 cases or $43.33 \%$ ), economy or finance (14 cases or $46.66 \%$ ), differences in character (12 cases or $40 \%)$, child problems (6 cases 20\%), extended family (2 cases or 6.6\%), verbal abuse (14 cases or $46.66 \%$ ), violating commitments (2 cases or $6.6 \%$ ), responsibility (4 cases or $13.33 \%$ ) ), physical violence (1 case $3.33 \%$ ), and disrespect for the partner (4 cases or $13.33 \%$ ). The details will be explained in the following table:

Table 1. Findings of the Narrative as Victims and Perpetrators

\begin{tabular}{lcc}
\hline \multicolumn{1}{c}{ Findings } & Victims (\%) & Perpetrators (\%) \\
\hline $\begin{array}{l}\text { The victim forgives } \\
\text { explicitly (openly/directly) }\end{array}$ & 66,66 & \\
The victim forgives & 33,33 & \\
implicitly (closed) & & \\
Domestic problems & & \\
1. Miscommunication & 30 & 13,33 \\
2. Economy/finance & 43,33 & 3,33 \\
3. Differences in character & 30 & 10 \\
4. Children & 10 & 10 \\
5. Extended family & 6,66 & - \\
\hline
\end{tabular}




\begin{tabular}{|c|c|c|}
\hline 6. Verbal abuse & 20 & 26,66 \\
\hline 7. Violation of commitment & 6,66 & - \\
\hline 8. Responsibility & 10 & 3,33 \\
\hline 9. Physical abuse & - & 3,33 \\
\hline $\begin{array}{l}\text { 10. Disrespect for the } \\
\text { partner }\end{array}$ & 13,33 & - \\
\hline \multicolumn{3}{|l|}{ Consequences } \\
\hline $\begin{array}{l}\text { 1. Relationship is } \\
\text { getting better }\end{array}$ & 36,66 & - \\
\hline $\begin{array}{l}\text { 2. Negative } \\
\text { consequences that are } \\
\text { felt after the event in a } \\
\text { long period of time }\end{array}$ & 13,33 & - \\
\hline \multicolumn{3}{|l|}{ Victim reaction } \\
\hline Angry & 30 & - \\
\hline Temporary & 33,33 & - \\
\hline avoidance & 26,66 & - \\
\hline Dissapointed & 26,66 & - \\
\hline Sad & 43,33 & - \\
\hline Annoyed & & \\
\hline \multicolumn{3}{|l|}{ The reaction of the perpetrator } \\
\hline $\begin{array}{l}\text { Regret for the } \\
\text { events that happened }\end{array}$ & - & 16,66 \\
\hline Self-blame & - & 16,66 \\
\hline Apologize & - & 43,33 \\
\hline Blame the partner & - & 16,66 \\
\hline
\end{tabular}

All respondents stated that the conflict that is felt or that occurs with their partner begins with a small conflict, which occurs in the marriage relationship, such as different opinions or misperceptions or miscommunication. There are various kinds of problems that are considered to trigger big fights, including violating commitment, responsibility, verbal violence, disrespect for partners, and physical violence.

Based on the results of the interview, it was found several things such as hurt feelings, their effect on relationships, reasons for forgiving, forms of forgiveness, and the process of forgiveness. The emotional wound perceived by the subject is the emotion felt by a person when experiencing a conflict with his partner. The emotional wounds that often occur when there is a conflict with a partner include disappointment, anger, sadness, and annoyance. Then the effect on the marriage relationship is that couples feel awkward to communicate with each 
other, this lasts only for a moment, and for bigger problems, the effect on the relationship will be greater, even some couples avoid their partners like they don't want to meet. partner. Then the reasons for forgiveness that are obtained from interviews are empathy, religion, commitment or promises given by the offending partner, social norms, for the sake of children or families, and dependence between partners. The form of forgiveness that is given is that most of the couples whose hearts have been hurt forgive their partners by truly forgiving, even though at first forgiveness is a difficult thing to do for all couples who are hurt but after going through a process, forgiveness can also occur for reasons that mentioned above.

Hypothesis testing for this study was conducted to determine the relationship between empathy and forgiving behavior. This test is carried out to prove whether or not there is a relationship between the two variables. Hypothesis testing is done using the correlation analysis technique product moment. The results of the analysis show that the value of the Pearson correlation between the variables of empathy and forgiveness behavior is 0.535 and a significance value of 0.002 ( $\mathrm{p}$-value $<0.05$ ), which means that the significance level between the two variables indicates a relationship between empathy and forgiveness behavior.

\section{Discussion}

This research reveals that all respondents stated that the conflict they feel or that occurs with their partner begins with a small conflict that occurs in the marriage relationship, such as different opinions, misperceptions or miscommunication. There are various kinds of problems that are considered to trigger violent arguments if they are related to parents-in-law, brother-inlaw and brother-in-law, violations of commitment, considered irresponsible, verbal abuse, disrespect for spouses and physical violence.

This conflict causes one of the partners to be drained of emotions which will lead to emotional wounds. The hurt feelings felt by one partner will be an obstacle to the continuation of a harmonious family. In a way, this emotional injury will affect the relationship between the party who has hurt his feelings and the partner who has hurt his feelings. This influence can take the form of the victim temporarily avoiding contact with the perpetrator until the intensity of the wound feeling heals or decreases. 
Forgiveness is an initial momentum to go further into the future together. Both parties should work together to rebuild a relationship as well as open a new page of interpersonal relationships between them. In forgiving, ideally, negative attitudes and feelings should be replaced with positive attitudes and feelings, but in fact this is not easy to do, especially quickly. There are always psychological problems between two parties who have experienced a relationship breakdown due to an error (Wardhati \& Faturochman, 2006). Therefore, adult forgiveness does not mean eliminating all negative feelings but becomes a balance of feelings (Smedes, 1984).

Conflicts that occur in a marriage relationship will involve emotions that result in emotional pain. Feelings hurt will present the desire to avoid your partner or respond to what you have felt or give a positive response, namely the desire to make peace with your partner. To give forgiveness to a partner who has hurt him, there must be a process that occurs. According to Smedes (1984), there are four stages in the process of forgiveness, namely: dressing hurt, relieving hatred, self-healing efforts and walking together.

In this study, all respondents said that they were trying to forget the mistakes their partners had made. The partner who was hurt also bandaged his hurt and tried to forgive his partner, which meant relieving the hatred that was in them.

This study also reveals that there are several factors that cause a partner who has been hurt to forgive a partner who has hurt him, namely: empathy, commitment or promise, religious and social norms and for the sake of their loved ones.

The results of research conducted by Arif (2013) which examined the relationship between commitments and forgiveness in friendly relationships showed that there was a significant positive correlation between the level of commitment and forgiveness given by individuals to their partners in a friendly relationship with proving the results of the analysis that gave rise to an $\mathrm{r}$ value of 0.355 with a $\mathrm{p}$ value of 0.000 . The higher the commitment that is built in a friendly relationship, the higher the forgiveness that the individual will give to his friend. The factors that also influence forgiveness behavior include: empathy, attribution of perpetrators and their mistakes, level of injury, personality characteristics and quality of relationships (Wardhati \& Faturochman, 2006). 
Empathy plays a positive role in forgiveness, the higher a person's ability to empathy, the higher his forgiveness. The ability of empathy allows a person to improve relationships with other people because empathy is one of the bases needed in building interpersonal relationships and can facilitate communication. Empathy is a feeling whose process is more complex than other emotions because this empathy arises based on observation or understanding of conditions, situations or feelings that are being experienced by other people, it turns out that it still plays a very significant role with forgiveness. This fact is in accordance with the expectations of researchers with regard to several opinions from the results of psychological research that empathy plays a positive role in forgiveness (Myung-Sun Chung, 2014; Davis \& Gold, 2011; Turnage, Hong, Stevenson, \& Edwards, 2012), also confirmed by empathy experts. requires cooperation between the ability to accept, understand cognitive and affective. The cognitive component functions for understanding the feelings of others, while the affective component in empathy is related to the ability to respond emotionally to the affective of others. Empathy is also social in nature because empathy is a person's ability to share in what other people suffer. Therefore, there is a relationship between empathy and forgiveness in accordance with expectations.

Using Huber and MacDonald's (2011) analysis of the relationship between empathy, altruism and spirituality, it is explained how forgiveness occurs. In the same way empathy makes it easier to understand other people's feelings, what is needed, including the need for forgiveness. In a close relationship that has been damaged by the hurtful behavior of either party, empathy for the offending party provides direct meaning in three ways. First, empathy causes the injured party to understand that the offending party feels guilty and pressured by behavior that hurts their partner and causes damage to their relationship. Second, empathy causes the injured party to understand the feelings of the offending party who is isolated in solitude due to being alienated from a relationship. Third, empathy for the party who has hurt the relationship, in other words empathy can lead to a desire to repair a positive relationship with the person who has hurt.

More specifically, the existence of empathy for someone can weaken the motivation to avoid the person who hurt and take revenge on that person and give more generous affection. 
People will develop empathy skills to strengthen relationships with others. Bethlehem, et al., (2016) stated that if everyone tries to put themselves in another person's position (empathizing) then misunderstandings, arguments or disagreements between individuals can be avoided. Thus it can be said that empathy plays an important role in one's relationships with others.

The ability of humans to give love is also reflected in their ability to be empathetic, namely the ability to feel, understand, and care about what other people are feeling. The suffering and happiness of others can seem to be felt so that it fosters a sincere attitude to give forgiveness to those in need, and this sincerity encourages the realization of a peaceful and peaceful society.

The results of the regression analysis stepwise to determine how much influence each aspect of the empathy variable has on forgiveness, it is obtained that the aspects perspective taking and personal distress have the most influence on forgiveness $(R=0.363)$ with the coefficient of determination. amounting to 0.086 . This means that $16 \%$ forgiveness in a close interpersonal relationship can be explained by the aspects of perspective taking and personal distress. Perspective taking is a person's tendency to take another's psychological point of view. Meanwhile, personal distress is self-oriented personal anxiety and anxiety in dealing with unpleasant interpersonal settings. Personal reactions to the suffering of others, feelings of shock, fear, anxiety, concern, pity and helplessness. Personal distress motivates a person to reduce anxiety by helping others in need, in this case forgiving people who have hurt.

The results of this study also show that forgiveness occurs when someone empathizes with the guilty person with anxiety about the guilty person's suffering and puts oneself into the person's mind. Assessment of painful events has a positive role in forgiveness, the more positive the assessment given by someone, the higher the forgiveness. An assessment of an event will affect every individual behavior. Judgments made by a person provide affective reactions that affect behavior. In the cognitive process, the victim realizes that the perpetrator feels guilty and does not mean to hurt so the victim looks for other causes and painful events. This change in assessment of painful events provides a positive emotional reaction which will then lead to forgiveness of the perpetrator (Burks, Youll, \& Durtschi, 2012). 
Forgiveness in close interpersonal relationships is one way of overcoming interpersonal conflicts. In a close interpersonal relationship, there are two interpersonal motivations in responding to painful events, namely first is feeling hurt, the injured individual and then avoiding psychological contact with the person who has hurt (avoidance). Both feelings of holding grudges, the individual who is hurt continues to hold grudges and wants to take revenge on those who have hurt (revenge) and a response of kindness (Batson, Lishner, \& Stocks, 2015). Forgiveness can be an attitude choice. Research shows that in a close relationship, a person tends to forgive their partner's mistakes because they have a relationship with high satisfaction, intimacy and commitment (McNulty, 2011). Therefore, people who forgive the mistakes of their friends or partners are very likely to improve the relationship between them.

\section{Conclusion}

Based on the results of the research and discussion previously described, it can be concluded that forgiveness in a close interpersonal relationship is one way of overcoming interpersonal conflict. Empathy and assessment of painful events play a positive role in forgiveness. The higher the ability of empathy and the better the assessment of painful events, the higher the individual's forgiveness in close interpersonal relationships.

Empathy plays a positive role in forgiveness, the higher a person's ability to empathy, the higher his forgiveness. Empathy can lead to the desire to repair a positive relationship with the person who has hurt. With empathy, individuals can feel, understand, and care about what other people are feeling. The suffering and happiness of others can be felt, so that it fosters a sincere attitude to apologize to people in need.

Assessment of painful events has a positive role in forgiveness, the more positive the assessment given by someone, the higher the forgiveness. Judgments made by individuals provide affective reactions that affect behavior and changes in assessment of painful events will provide positive emotional reactions which will then lead to forgiveness of the perpetrator. Advice

Forgiving a partner who has hurt is not easy, but if someone can apologize to his partner who made a mistake then indirectly he has done something positive for himself and his partner, 
namely releasing the anxiety that occurs in him and for his partner so that can improve their psychological condition after making a mistake, it aims to create positive interactions between partners.

\section{References}

Arif, T. A. (2013). Komitmen Dengan Pemaafan Dalam Hubungan Persahabatan. Cognicia, 1(2). $11-22$.

Bantham, J. H., Celuch, K. G., \& Kasouf, C. J. (2003). A Perspective Of Partnerships Based On Interdependence And Dialectical Theory. Journal of Bussiness Research, 56(4), 265-274.

Basri, H. (2020, February 15). Interview of "angka perceraian di kota padang" on his office. Durian Tarung Street No. 1. Padang.

Batson, C. D., Lishner, D. A., \& Stocks, E. L. (2015). The Empathy-Altruism Hypotesis. In D. A. Schroeder, \& W. Graziano, The Oxford Handbook of Prosocial Behavior. New York: Oxford University Press.

Bethlehem, R. A., Allison, C., Andel, E. M., Coles, A. I., Neil, K., \& Baron-Cohen, S. (2016). Does Empathy Predict Altruism In The Wild? Social Neuroscience, 12(6), 743-750.

Boiger, M., \& Mesquita, B. (2012). The Construction Of Emotion In Interactions, Relationships, And Cultures. Emotion Review, 4(3), 221-229.

Braithwaite, S. R., Selby, E. A., \& Fincham, F. (2011). Forgiveness And Relationship Satisfaction: Mediating Mechanisms. Journal of Family Psychology, 25(4), 551-559.

Brock, R. L., \& Lawrence, E. (2014). Intrapersonal, Interpersonal, And Contextual Risk Factors For Overprovision Of Partner Support In Marriage. Journal of Family Psychology, 28(1), 54-64.

Burks, D. J., Youll, L. K., \& Durtschi, J. P. (2012). The Empathy-Altruism Association and Its Relevance To Health Care Professions. Social Behavior and Personality: An International Journal, 40(3), 395-400.

Chaplin, R. (2019). Taking It Personally: Third-Party Forgiveness, Close Relationships, And The Standing to Forgive. Oxford Studies in Normative Ethics, 9, 73-94.

Creswell, J. W. (2012). Research Design: Qualitative, Quantitative, And Mixed Methods (Third ed.). Yogyakarta: Pustaka Pelajar.

Cuff, B. M., Brown, S. J., Taylor, L., \& Howat, D. (2014). Empathy: A Review Of The Concept. Emotion Review, 8(2), 144-153.

Davis, J. R., \& Gold, G. (2011). An Examination of Emotional Empathy, Attributions of Stability, and The Link Between Perceived Remorse and Forgiveness. Personality and Individual Differences, 50(3), 392-397.

Enright, R. D., Gassin, E. A., \& Wu, C.-R. (2006). Forgiveness: a Developmental View. Journal of Moral Education, 21(2), 99-114.

Everett L., \& Worthington, J. (2005). Handbookff Forgiveness. New York: Routledge.

Fabes, R., Peterson, G. W., \& Steinmetz, S. (2002). Emotions and The Family. New York: Routledge. 
Fincham, F. D., Paleari, F. G., \& Regalia, C. (2002). Forgiveness In Marriage: The Role of Relationship Quality, Attributions, And Empathy. Personal Relationships, 9(1), 27-37.

Friesen, M. D., Fletcher, G. J., \& Overall, N. (2005). A Dyadic Assessment of Forgiveness In Intimate Relationships. Personal Relationships, 12(1), 61-77.

Griffin, B. J., Jr, E. L., Lavelock, C. R., Wade, N. G., \& Hoyt, W. (2015). Forgiveness And Mental Health: Scientific Evidence and Theories Relating Forgiveness to Better Health. In L. Toussaint, E. Worthington, \& \&. D. Williams, Forgiveness and Health (pp. 77-90). New York: Springer.

Helen Riess, MD. (2017). The Science of Empathy. Journal of Patient Experience, 4(2), 74-77.

Howe, D. (2013). Empathy: What It Is and Why It Matters. New York: Palgrave Macmillan.

Huber, J.T II., \& MacDonald, D. (2011). An Investigation of The Relations Between Altruism, Empathy, and Spirituality. Journal of Humanistic Psychology, 52(2), 206-211.

Lanzoni, S. (2018). Empathy: a History. London: Yale Universty Press.

Macaskill, A. (2012). Differentiating Dispositional Self-Forgiveness From Other-Forgiveness: Associations With Mental Health and Life Satisfaction. Journal of Social and Clinical Psychology, 31(1), 28-50.

McCullough, M. E., Kurzban, R., \& Tabak, B. (2013). Cognitive Systems for Revenge and Forgiveness. Behavioral and Brain Sciences, 36, 1-15.

McCullough, M. E., Rachal, K. C., Sandage, S. J., Worthington, E. L., S. W. Brown, J., \& Hight, T. (1998). Interpersonal Forgiving In Close Relationships: Ii. Theoretical Elaboration and Measurement. Journal of Personality and Social Psychology, 75(6), 1586-1603.

McNulty, J. K. (2011). The Dark Side ff Forgiveness: The Tendency to Forgive Predicts Continued Psychological and Physical Aggression In Marriage. Personality and Social Psychology Bulletin, 37(6), 770-783.

Mubarok, A. (2009). Psikologi Keluarga. Jakarta: Wahana Aksara Prima.

Myung-Sun, C. (2014). Pathways Between Attachment and Marital Satisfaction: The Mediating Roles of Rumination, Empathy, and Forgiveness. Personality and Individual Differences, 70, 246-251.

Nugroho, A. S. (2020, October 3). Islam Digest. Retrieved from Republika.co.id: https://republika.co.id/berita/qb6u6h430/abu-bakar-ash-shiddiq-sahabat-terdekat-nabimuhammad

Riek, B. M., \& Mania, E. (2012). The Antecedents and Consequences of Interpersonal Forgiveness: A Meta-Analytic Review. Personal Relationships, 19(2), 304-325..

Rusbult, C. E., \& Verette, J. (1991). An Interdependence Analysis Of Accommodation Processes In Close Relationships. Representative Research in Social Psychology, 19(1), 3-33.

Shihab, M. Q. (2002). Tafsir Al Misbah: Pesan, Kesan Dan Keserasian. Jakarta: Lentera Hati.

Smedes, L. B. (1984). Forgive And Forget: Healing The Hurts We Don't Deserve. New York: HarperCollins.

Toussaint, L. L., Owen, A. D., \& Cheadle, A. (2012). Forgive To Live: Forgiveness, Health, And Longevity. Journal of Behavioral Medicine, 35, 375-386.

Turnage, B. F., Hong, Y. J., Stevenson, A. P., \& Edwards, B. (2012). Social Work Students' Perceptions of Themselves and Others: Self-Esteem, Empathy, And Forgiveness. Journal of Social Service Research, 38(1), 89-99. 
Wade, N. G., Hoyt, W. T., Kidwell, J. E., Worthington, J., \& Everett, L. (2014). Efficacy of Psychotherapeutic Interventions to Promote Forgiveness: A Meta-Analysis. Journal of Consulting and Clinical Psychology, 82(1), 154-170.

Wardhati, L. T., \& Faturochman. (2006). Psikologi Pemaafan. Buletin Psikologi, 14, 57-67.

\begin{tabular}{|l|l|l|l|l|}
\hline Submit & Review & Revisi & Diterima & Publis \\
\hline 02-11-2020 & 26-03-2021 sd 04-04-2021 & 07-04-2021 & 09-04-2021 & 10-06-2021 \\
\hline
\end{tabular}

Faisal Adnan Reza, Subhan Ajrin Sudirman, Mubarak Mubarak

Universitas Islam Negeri (UIN) Raden Intan Bandar Lampung,

Universitas Islam Negeri (UIN) Imam Bonjol Padang, Universitas Islam Negeri (UIN) Antasari Banjarmasin

Email : faisaladnan@radenintan.ac.id, subhansudirman@uinib.ac.id, mubarak_pi@uin-antasari.ac.id 